Piotrowska, M. (2019). Facets of Competitiveness in Improving the Professional Skills. Journal of

Competitiveness, 11(2), 95-112. https://doi.org/10.7441/joc.2019.02.07

\title{
FACETS OF COMPETITIVENESS IN IMPROVING THE PROFESSIONAL SKILLS
}

\section{- Maria Piotrowska}

\begin{abstract}
The goal of the study is to examine age- and gender-differences between employees in regards to motivation for training. Four facets of competitiveness and three types of orientation in extrinsic motivation are considered. In a Hayes conditional process analysis, the research uses the data from a questionnaire survey carried out in Poland in 2016 among higher-educated employees at mobile-working age. Our findings show that the competition in self-development is the most important facet of competitiveness for under 40-year-olds, while it is competing in terms of enjoying the job for employees of age 39-45. Competing in terms of financial compensation was shown to be the least important facet in each age group. In general within each age group, the participants were shown to be more strongly stimulated to improve their skills by less extrinsic forms of motivation. Higher-educated women and men are motivated to improve their professional skills by the same stimuli up to the end of their $40 \mathrm{~s}$, after which less extrinsic motivation (self-development and autonomy) become more important for men than women. The findings contribute to the literature on competitiveness and motivation, suggesting a number of recommendations in terms of how to organize training for employees of different age groups, contributing to the overall growth of productivity within an economy.
\end{abstract}

Keywords: competitiveness, employees, skills, motivators JEL Classification: J24

Received: May, 2018

1st Revision: February, 2019

Accepted: May, 2019

\section{INTRODUCTION}

Competitiveness can be considered from both the economic and psychological point of view. In the Global Competitiveness Reports prepared by the World Economic Forum (2016) in 1979, economic competitiveness is defined as "the set of institutions, policies and factors that determine the level of productivity of a country" (WEF webpage, What Is Competitiveness). As the World Economic Forum (2016) measures economic competitiveness, it breaks down competitiveness among countries into 12 distinct areas, or pillars, which are grouped into three sub-indexes. The first of these, "basic requirements," includes institutions, infrastructure, macroeconomic environment, health and primary education. The second sub-index, "efficiency enhancers," refers essentially to markets, but also considers higher education and training as well 
as technological readiness, parameters which measure how well economies are prepared for the transition to a more advanced state. The third sub-index, "innovation and sophistication," consists of two pillars: business sophistication and innovation. The framework of economic competitiveness points at job training as a key pillar which allows middle-income countries to move toward knowledge-based economies. The need to improve work-related skills links economic and psychological approaches to competitiveness in the workplace.

Competitiveness can be examined not only in economic terms but also as a personality trait which drives people to compete. Individual differences in competitiveness, or the inclination to compete, can have critical effects on improving work-related skills in achievement situations. As an example, individuals lower in competitiveness, interpreted as a personality trait, decrease the value of training, which results in a lower performance in the competitive climate.

The differences in competitiveness among employees do not come down merely to the essential (weaker or stronger) inclination to compete. Variances can result from differences in motivation. Ryan \& Deci (2000) stress that people vary not only in the level of motivation (i.e. how much), but also in the orientation of that motivation (i.e. what type). The orientation of motivation is characterized by underlying attitudes and goals that cause or limit the advancement to action (i.e. why actions are undertaken).

Employees can desire different outcomes as they improve their professional skills. In the present paper, it is presumed that employees will involve themselves more in job training when higher skills would result in one of four outcomes: increased wealth, prestige, self-development, or enjoyment from the job. Achieving each of these four outcomes requires a different mechanism by which improving skills transmits to concrete effects. If the employee wants to increase wealth, higher skills are sought with the goal of higher earnings. If professional prestige is desired, the job training should lead to a promotion. If the person wants to self-develop, the job training should create such possibilities in the current job as well as in the future. If the employee seeks a job which would enhance enjoyment, higher skills should provide, e.g. greater autonomy in the job. The desire to achieve these four outcomes motivates employees to use improvement in work-related skills as a tool in the competition for higher earnings, promotions, possibilities to self-develop, or obtaining a high level of autonomy in the workplace. Knowledge of the mechanisms by which improvement in professional skills influences outcomes desired by employees allows training developers to choose the suitable motivators of job training. As a consequence, more employees are interested in improving their skills and, therefore, the job training is more efficient and the overall economy obtains an "efficiency enhancer" which helps to facilitate its transition to a knowledge-based economy.

The motivators of job training can vary for different groups of employees. Therefore, the aim of this research is to reveal age and gender differences in the mechanisms by which improvement in professional skills influences outcomes desired by employees with different dimensions (facets) of competitiveness. These facets (dimensions) are here defined as competing to be well-off, competing to avoid relative professional deprivation, competing to self-develop, and competing to enjoy the job.

People with the first dimension of competitiveness, competing to be well-off, want to feel supe- 
rior to their neighbors in terms of financial compensation. They must feel that are wealthier than others in order to feel good about themselves. People with the second facet of competitiveness, competing to avoid relative professional deprivation, compete in terms of professional prestige. They want to achieve at least the same working conditions as their workmates to avoid relative professional deprivation. Townsend (1979) defines relative deprivation as a lack of resources to sustain a certain lifestyle, activities and amenities that an individual or group are accustomed to, or that are widely encouraged or approved in the society to which they belong. Deprivation is relative when it comes to comparisons of social norms. Individuals with the first and the second facet of competitiveness feel the need to make social comparisons, as how they rank with others is relevant in defining their self- worth.

The third facet of competitiveness, competing to self-develop, indicates a situation in which the main motivators are self-improvement and self-discovery, i.e. superiority is not a driving force. The fourth facet, competing to enjoy the job, refers to employees who are motivated by the ability to do what they like in their professional life.

Employees with these four facets of competitiveness experience extrinsic motivations. In terms of Self-Determination Theory, Deci \& Ryan (1985) have distinguished two types of motivation: intrinsic and extrinsic motivation. Intrinsic motivation refers to doing something because it is inherently interesting or enjoyable, and extrinsic motivation refers to doing something because it leads to a separable outcome (Ryan \& Deci, 2000, p. 55). In this paper, employees are assumed to be stimulated to improve their professional skills by three types of extrinsic motivations: introjection, identification and integration, as defined by Ryan \& Deci (2000, pp. 61-62).

A classic form of introjection is ego involvement (Nichols, 1984; Ryan, 1982), in which a person does something in order to enhance or maintain self-esteem and the feeling of worth. Employees with the first and second facet of competitiveness, competing to be well-off and competing to avoid relative professional deprivation, are motivated to participate in continuing education by introjection. They expect that higher work-related skills will contribute to a salary rise and career promotion. These typical extrinsic rewards allow them to place themselves in higher positions in the rankings of wealth and professional prestige, or to enhance their self-worth.

A more self-determined form of extrinsic motivation is the regulation through identification. "Here, the person has identified himself/herself with the personal importance of behavior and has thus accepted its regulation as his or her own" (Ryan \& Deci, 2000, p.62). Employees with the third facet of competitiveness, competing to self-develop, are motivated to participate in training by identification. They continue learning not because it is interesting and enjoyable itself, but because they see it as relevant to their professional development, which they value as a life goal. They have identified themselves with the value of this learning activity.

The most self-determined form of extrinsic motivation is integration. Employees who are motivated by integrated regulation also see improving work-related skills as the instrument through which they can extend the opportunities of doing what they like to do. Higher professional skills allow them to move on to a position in an organization in which they can enjoy their job.

There are predictable reasons for movement between the types of motivation over a life span. A shift has been suggested from the least autonomous form of extrinsic motivation to intrinsic mo- 
tivation, e.g. Inceoglu et al. (2012) proposed four groups of psychological processes that are likely to affect work motivation: 1) changes in personal resources; 2) changes in the perceived utility of specific work-related outcomes; 3) moving through different stages of the life cycle and 4) social comparisons and social pressures. The orientation of motivation can also vary by gender.

The present research deals with higher-educated employees who have attained at least a bachelor's or master's degree. Such a choice of participants allows the researchers to avoid a simple moderating impact of schooling on the relationship between age and continuing education, as adults with higher levels of education are more likely to pursue self-development (Warr \& Birdi, 1998). Moreover, with increased crystallized intelligence, older and higher-educated employees need to exert less effort in the area of their expertise to reach the same performance outcome as younger novices (Kanfer \& Ackerman, 2004).

This study contributes to the existing research by supporting developmental approaches to motivation by examining the facets of competitiveness with extrinsic orientation. The research clarifies the nature of motivational processes which are involved with competition when employees improve their professional skills.

The empirical research in the paper is based on data coming from the questionnaire survey carried out in Poland in 2016. Poland is a good case for such a study because of the transition process from a central planning economy to a market economy that the Polish society have experienced. The Social Diagnosis carried out by Czapiński \& Panek (2003, 2007-2018) gives an insight into the process of system transformation. It is the diagnosis of the conditions and quality of life of the Poles as they report it. The reports provide detailed data derived from institutional indicators concerning households and the attitudes, mind-sets and behaviors. The data point that many opportunities to develop career paths have occurred, especially for younger generations (see also Turska (2017)), as well as many opportunities to improve material status. People have used social comparison to rank with others. Employees expect progress in development of their professional skills. Career has become a life goal in terms of either professional prestige and wealth or self-development. Those, who have not wanted or have not been able to move on to higher positions in the structures of their organizations, have moved to such teams where they could do what they like to do. A crucial instrument to reach the life goal, prestige, wealth, selfdevelopment, or enjoyment, is training that allows to place on the suitable posts in organizations. According to the Polish Labour Code, employees could expect from employers to provide them with training that improved their professional skills in a desired direction.

This paper is structured as follows. The second section presents the background providing the theoretical foundations and empirical evidence included in the literature. The third section describes the data, method and research objectives. The fourth section covers the results and discussion on them as well as the contribution of this paper to the literature. The fifth section points at the research limitation and further studies. Finally, the sixth section presents the conclusions. 


\section{BACKGROUND}

This paper is based on three keystones: an approach to competitiveness, as a personality trait developed by Griffin-Pierson (1990) and Kayhan (2003), the taxonomy of types of motivation proposed by Ryan \& Deci (2000) and empirical evidence on age-and gender-related changes in adult development which affect work motivation prepared by Inceoglu et al., 2012.

In research presented in the literature, the first facet of competitiveness is usually related to the strong desire of winning, dominating or being superior to others, while the second one refers to the desire for excellence, obtaining a goal, bringing out the best one can do, mastering the task, and developing oneself (Orosz et al., 2018). As an example, Hibbard \& Buhrmester (2010) called these two types of competitiveness as competing to win (to dominate others) and competing to excel (to surpass personal goal).

In Self-Determination Theory, Deci \& Ryan (1985) developed a sub-theory, called Organismic Integration Theory, to introduce the different forms of extrinsic motivation. They proposed the taxonomy of types of motivation arranged in terms of the extent to which the motivation for one's behavior emanates from oneself (Ryan \& Deci, 2000, Figure 1, p.61). The first type of extrinsic motivation is a category, labeled external regulation, that represents the least autonomous forms of extrinsic motivation. It is characterized by salience of extrinsic rewards and punishments. The second type of extrinsic motivation is interjected regulation focused on approval from self or others. The third form of extrinsic motivation, regulation through identification, is a more autonomous, or self-determined. The fourth type of extrinsic motivation, labeled integrated regulation, is the most autonomous form of extrinsic motivation. Integration occurs when regulations have been fully assimilated to the self.

The taxonomy through four extrinsic motivations "is not a developmental continuum, per se" (Ryan \& Deci, 2000, p. 62). A person does not have to progress through each type of motivation. There is no necessary "sequence", however, psychological processes are likely to affect work motivation and to generate a shift in people's motives over time: older employees are less motivated by extrinsically but more intrinsically-rewarding features (Inceoglu et al., 2012). Agerelated changes in adult development may affect work motivation in three ways (see the summary prepared by Inceoglu et al., 2012, pp. 4-5).

Firstly, people experience a decline in fluid intelligence (e.g. working memory, processing of new information) with older age (Cavanaugh \& Blanchard-Fields, 2006; Lee et al., 2005; Schaie, 2005) and an increase in crystallized intelligence (educational or experimental knowledge (Kanfer \& Ackerman, 2004). Warr \& Fay (2001) found that older adults were less likely to engage in education initiatives (e.g. participating in continuing education, future self-development intentions). Education can, however, moderate the relationship between age and continuing education, as adults with higher levels of education are more likely to pursue self-development (Warrr \& Birdi, 1998).

Secondly, over the life span, employees can differently perceive the importance of job feature and performance outcomes. If age is associated with less opportunities for external rewards (e.g. pay rises) and career progression (e.g. promotion), older employees tend to perceive the extrinsic instrumentality (e.g. salary increase, professional advancement) of training activities to be lower 
(Guerrero \& Sire, 2001) and are less likely to see the need to improve work-related skills (Maurer et al., 2003, Inceoglu et al., 2012).

Thirdly, there is a shift in motives because of changes in life-goals and self-concept. More extrinsic, competitive patterns of achievement are replaced with age by more intrinsic, task-oriented patterns (Maehr \& Kleiber, 1981). Kanfer and Ackerman (2000) found mean scores of under 30 -year-olds to be higher on achievement and competitive excellence-oriented scales compared to over 30-year-olds. Inceoglu et al. (2012) revealed that extrinsically rewarding job futures such as material rewards, career progression and status were less motivating in older age groups.

Nnambooze \& Parumasur (2016) confirmed that generational differences exist in terms of an interesting and motivating work environment, a flexible and efficient work environment and, opportunities for learning and diversity.

Finally, gender differences may explain the differentiation and the movement in motivation. It has been found that achievement (Kanfer \& Ackerman, 2000; Warr, 2008), power, the opportunity to use initiative, a responsible job, and good chance to promotion are important motivation for men, while women are stimulated by working with pleasant people, meeting people and having flexible hours of work (Warr, 2008). Inceoglu et al. (2012) found that the extent to which status motives men is stable over age, but not in the case of women. For women, status became slightly less important until the age of 46 to 55 years, after which it was valued more. The literature survey on gender differences in competitiveness is presented by Böheim et al. (2017).

This study focuses on competitiveness defined as a personality trait or the inclination to compete. Four facets of competitiveness considered in the paper vary in the orientation of motivation. They are determined by different forms of extrinsic motivation.

\section{SAMPLE, METHOD AND RESEARCH OBJECTIVES}

A source of data is a questionnaire survey carried out in Poland in November of 2016. Respondents have attained a tertiary educational level. They were in 25-45-year age; it is in their mobile working age (in Poland, students graduate from universities when they are 24). The employees of age up to 45 are included in the research to avoid two issues which can influence motivation to participating in continuing education. Firstly, the decline in fluid ability of older employees (e.g. beyond middle age) can result in less engaging in education initiatives because of learning difficulties and a lower self-confidence (self-efficacy) in learning. It is assumed that the attractiveness of job features that require a lot of personal resources is likely to decline considerably not earlier then when workers reach middle age (Kanfer \& Ackerman, 2004). Secondly, older employees are less likely to experience prospects for progression in later career life.

In November of 2016, interviews were carried out with respondents using CAPI (Computer-assisted personal interviewing) method, on a nationwide, random-quota sample with a conscious choice of the respondent. Because of the criteria used for selecting the participants (age range, higher education), the appropriate sub-groups are representative for the respective sub-populations (with respect to marginal distributions) due to age and gender, as well as a voivodship (Poland is divided into 16 administrative units called voivodships) and a place of residence (towns, village). 
The official Polish system of household records (TERYT) was used to draw the sample. The same system is used for representative surveys conducted by the Central Statistical Office (but the study was conducted by an independent, reputable research agency). This allows the generalization of the results on considered parts of the population.

The sample of respondents is divided into three age-groups of employees: 1) the young, 25-31, (272 respondents, 2) the younger in middle age, 32-38, (271 respondents); 3) the older in middle age 39-45, (283 respondents). The percentage of women is increasing across the age groups (51\%, 57\% and $69 \%$, respectively). There is no difference in the place of residence between the age groups. The fraction of participants lives in a big city (more than 200 thousand habitants) is $33 \%, 34 \%$ and $35 \%$, respectively; in a medium-size town (50-200 thousand habitants) $19 \%$, $18 \%$ and $19 \%$, respectively; and in a small town (up to 50 thousand habitants) $24 \%, 23$. And $23 \%$ respectively. The mean income after tax increases, but slightly, across the age groups (580 EUR, 613 EUR and 619 EUR, respectively), while the median income remains the same (576 EUR), what points at a small enhancement of income inequality. The older in the middle age (39-45 years), who studied at universities in the 90s, or during the first stage of social-economic transition, evaluated the quality of education attained lower than two other groups. In general, more or less 40 percent (50 percent) of the participants perceived the quality of teaching at their universities (secondary schools) as not high. The quality of learning is measured by the items: Your university (secondary school) has maintained a high level of teaching and obtained a high position in a ranking of universities (secondary schools), at a five-point scale; $1=$ strongly disagree, $5=$ strongly agree.

The purpose of this research is to reveal the age and gender differences in the mechanisms by which improvement in professional skills influences outcomes desired by employees with different dimensions (facets) of competitiveness. The method chosen in the paper allows to achieve this goal.

The research is based on the conditional process analysis. Hayes (2013) determines this method as a modeling strategy undertaken with the goal of describing the conditional or contingent nature of the mechanism(s) by which a variable transmits its effect on another, and testing hypotheses about such contingent effects. The method covers two ideas: mediation analysis and moderation analysis. Mediation analysis is used to quantify and examine the direct and indirect pathways through which an antecedent variable $\mathrm{X}$ transmits its effect on a consequent variable $\mathrm{Y}$ through an intermediary $\mathrm{M}: \mathrm{X} \rightarrow \mathrm{M} \rightarrow \mathrm{Y}$ is a causal chain of event.

The variables are constructed on a base of items in the questionnaire survey. The response scale consists of a 5 -point rating scale with the following response options: $1=$ strongly disagree; $2=$ slightly disagree; $3=$ neither agree or disagree; $4=$ slightly agree; $5=$ strongly agree.

The measures of the antecedent variable $\mathrm{X}$ and the consequent variables Ys are patterned on the items used in the index of person-environment fit (see for example Chuang et al. (2016)) as well as on the items which arise from relative deprivation theory (see for example Crosby (1984)).

The antecedent variable X, Improving professional skills, is measured by the item: The present job meets your expectations and needs for improving skills. 
There are four consequent variables Ys, corresponding to four goals which motivate employees to improve their skills. Employees with the facet of competitiveness named competing to be well-off, are motivated by a raise in relative wealth. The Relative wealth, the first consequent variable $\mathrm{Y}$, is reflected by relative well-being, or self-comparison between employee's wealth and the wealth of the others who live in the same area (wealth of neighbors) and measured by the item: Please, evaluate your material situation in comparison to the others who live in the same area on a scale from $1=$ your material situation is much worse to $5=$ your material situation is much better.

Employees with the facet of competitiveness, named competing to avoid relative professional deprivation, are motivated by professional prestige. Professional prestige, the second consequent variable $\mathrm{Y}$, is measured by the item: Your working conditions (e.g. tasks, responsibility, promotion opportunity, earnings and benefits) are like working conditions of your university mates (or persons with the same skills in other organizations). It is assumed that a minimum goal of competition between mates is to avoid relative deprivation, or to achieve at least the same standard of working conditions.

The third consequent variable $\mathrm{Y}$, labeled Opportunity of professional development in the future outside the current organization, for employees with the facet of competitiveness named competing to self-development, is measured by the item: In the future you have many opportunities for professional development in other organizations.

The fourth consequent variable $\mathrm{Y}$ refers to employees with the facet of competitiveness named competing to enjoy job. This variable is labeled Job enjoyment and measured by the item: In your present job you do what you like to do.

The indirect pathway through which an antecedent variable $\mathrm{X}$ transmits its effect on a consequent variable $\mathrm{Y}$ through an intermediary $\mathrm{M}$ is a causal chain of event: $\mathrm{X} \rightarrow \mathrm{M} \rightarrow \mathrm{Y}$ (see Figure 1 ).

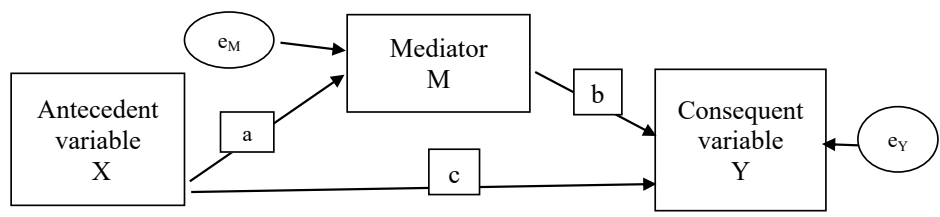

Fig. 1 - The statistical model 4 in the Hayes Process. Source: Darlington \& Hayes (2016)

Indirect effect of $\mathrm{X}$ on $\mathrm{Y}$ through $\mathrm{M}=\mathrm{ab}$

Direct effect of $\mathrm{X}$ on $\mathrm{Y}=\mathrm{c}^{\prime}$

The first step in this research is to identify the causal chain of event for each of the competitiveness facets. The following causal chains of events are expected to be significant:

1. For competing to be well-off, e.g. the facet of competitiveness with regulation through introjection improving the professional skills $\rightarrow$ earnings $\rightarrow$ relative wealth 
2. For competing to avoid relative professional deprivation, e.g. the facet of competitiveness with regulation also through introjection improving the professional skills $\rightarrow$ promotions $\rightarrow$ professional prestige

3. For competing to self-develop, e.g. the facet of competitiveness with regulation through identification improving the skills $\rightarrow$ ability of professional development in the current organization $\rightarrow$ opportunity of professional development in the future outside the current organization

4. For competing to enjoy the job, e.g. the facet of competitiveness with regulation through integration improving the professional skills $\rightarrow$ autonomy in the current organization $\rightarrow$ job enjoyment

The employees who compete to be well-off or to avoid relative professional deprivation pursue their ends (wealth and/or prestige) through pay rise and promotion. The employees, who compete to self-develop, improve their work-related skills to raise their ability of professional development in their current organizations, finally to broaden their professional opportunities in the future outside their organizations. Employees who compete to enjoy job must enhance their autonomy to do what they like to do. Therefore, earnings, promotions, the ability of professional development in the current organization and autonomy are expected to be mediators and they are measured by the following items on a five-point scale; $1=$ strongly disagree, $5=$ strongly agree:

- Promotion: The present job meets your expectations and needs for promotions and progress in your career plans.

- Earnings: The present job satisfies you with earnings.

- Ability of professional development in the current organization: You have the ability of professional development in the current organization.

- Autonomy: The present job meets your expectations and needs for autonomy.

The second step in this study is to find out the age and gender differences in the causal chains of the events described above. The mediation analysis is carried out for three age samples of the participants. The moderation analysis is used to examine gender differences in each age group. Gender can be a moderator, W, that strengthens or weakens the effect of the variable $\mathrm{X}$ on the mediator, $\mathrm{M}$, e.g. $\mathrm{X} \rightarrow \mathrm{M}$ (the model 7 in the Hayes process analysis, Darlington \& Hayes, (2016)), and/or the effect of the mediator, $\mathrm{M}$, on the variable $\mathrm{Y}$, e.g. $\mathrm{M} \rightarrow \mathrm{Y}$ (the model 14 in the Hayes process analysis, Darlington \& Hayes, (2016)). The importance of gender differences is confirmed in four steps by the significance of: (1) the test of highest order unconditional interaction, (2) conditional effects of the focal predictor at values of the moderator (gender), (3) conditional indirect effects of $\mathrm{X}$ on $\mathrm{Y}$, and finally (4) the index of moderated mediation (the difference between conditional indirect effects).

Almost all variables used in the study are Likert data (except Gender variable; the consequent variable Y1: Relative wealth measured by the item: Evaluate your material situation in comparison to the others who live in the same area which is not based on the typical Likert responses, but it is measured on a 5-point scale; Age which is an interval variable). 
The usage of Likert data requires considering the controversy on the ability to apply the mean, standard deviation and correlation, and to run t-tests and use the variables based on this type of the data as predictors in a regression. In general, there are two contrary standpoints in the discussion on this problem. Some researchers follow the Jamieson (2004) argument that the response categories have a rank order but the intervals between values cannot be presumed equal. The consequence is that the appropriate descriptive and inferential statistics differ for ordinal and interval variables and if the wrong statistical technique is used, the researcher increases the chance of coming to the wrong conclusion. However, other experts accept Carifio \& Perla (2008) opinion that if the data are normally distributed (or nearly normal), parametric tests can be used with the Likert scale ordinal data.

Many researches have been convinced by findings from empirical literature dating back nearly 80 years, carried out by Norman (2010), one of world's leaders in medical education research methodology. Reviewing this controversy on Likert data, Norman did not focus on assumptions but he directly addressed the issue of robustness. He pointed that Pearson (1931, 1932a, b), Dunlap (1931) and Havlicek \& Peterson (1976) have all shown, using theoretical distributions, that Pearson correlation is robust with respect to skewness and non-normality. Norman (2010) confirmed these results with some real scale data. Summarizing the empirical literature survey Norman (2010) concluded that parametric statistics can be used with Likert data, with small sample sizes, with unequal variances, and with non-normal distributions with no fear of coming to the wrong conclusion.

In general, this paper accepts Norman's findings that parametric statistics can be used with Likert data with no fear of coming to wrong conclusion (Norman, 2010), however, it also takes into account Carifio \& Perla's opinion (2008) that if the data distribution is nearly normal, parametric tests can be used with the Likert scale ordinal data.

None of the variable used in this research has the perfectly normal distribution. It means that no distribution has the skewness equal to 0 and the kurtosis (measured as an excess kurtosis) equal to 0 . However, all variables are only moderately skewed. Their skewness is between -1 and -0.5 or between 0.5 and 1 . Two variables, Relative wealth and Prestige are even fairly symmetric (skewness, by the age groups, is equal to $-0.119 ;-0.209 ;-0.171$ and,$- .0313 ;-0.357 ;-0.331$ respectively). The distributions of almost all variables have the excess kurtosis between 0 and 0.5 or between 0 and -0.5 (except three variables for the age group named older in the middle age: Improving skills, kurtosis $=1.159$; Autonomy, kurtosis $=1.227$ and Job enjoyment, kurtosis $=0.695$ ). It means that the extreme values of the distribution for all variables are moderately similar to that of the normal distribution characteristic. The values of skewness and kurtosis suggest that the distributions of all variables used in this research are at least moderately normal. This finding together with Norman's conclusion (Norman, 2010) allows to use the mediation analysis in the research.

\section{RESULTS AND DISCUSSION}

Table 1 covers the values of the indirect effects, it means, the effects of improving the skills related to each of four goals (the variables Y) through the respective mediator by the age groups. 
All four expected causal chains of events occur to be statistically significant at the level of $5 \%$.

Tab. 1 - The indirect effects of improving the professional skills. Source: Own calculation on a base of the model 4 in the Process Hayes in SPSS

\begin{tabular}{|c|c|c|c|c|c|c|}
\hline \multirow{3}{*}{$\begin{array}{l}\text { Facet of } \\
\text { competi- } \\
\text { tion }\end{array}$} & \multirow{3}{*}{$\mathrm{Y}$} & \multirow{3}{*}{ Age } & \multicolumn{4}{|c|}{ Mediator (M) } \\
\hline & & & $\begin{array}{l}\text { Earn- } \\
\text { ings }\end{array}$ & $\begin{array}{l}\text { Promo- } \\
\text { tions }\end{array}$ & $\begin{array}{l}\text { Ability of } \\
\text { professional } \\
\text { development } \\
\text { in the current } \\
\text { organization }\end{array}$ & $\begin{array}{l}\text { Autonomy in } \\
\text { the current } \\
\text { organization }\end{array}$ \\
\hline & & & \multicolumn{4}{|c|}{ Indirect effect of $\mathrm{X}$ on $\mathrm{Y}$ through the mediator $(\mathrm{M})$} \\
\hline \multirow{3}{*}{$\begin{array}{l}\text { Compet- } \\
\text { ing to be } \\
\text { well-off }\end{array}$} & \multirow{3}{*}{ Relative wealth } & $25-31$ & $0.0644^{* *}$ & & & \\
\hline & & $32-38$ & $0.0677 * *$ & & & \\
\hline & & $39-45$ & $0.1246^{* *}$ & & & \\
\hline \multirow{3}{*}{$\begin{array}{l}\text { Compet- } \\
\text { ing to } \\
\text { avoid rela- } \\
\text { tive profes- } \\
\text { sional } \\
\text { deprivation }\end{array}$} & \multirow[b]{3}{*}{$\begin{array}{l}\text { Professional } \\
\text { prestige }\end{array}$} & $25-31$ & & $0.1405^{* *}$ & & \\
\hline & & $32-38$ & & $0.1096^{* *}$ & & \\
\hline & & $39-45$ & & $0.1594 * *$ & & \\
\hline \multirow{3}{*}{$\begin{array}{l}\text { Competing } \\
\text { to self-de- } \\
\text { velop }\end{array}$} & \multirow{3}{*}{$\begin{array}{l}\text { Opportunity } \\
\text { of professional } \\
\text { development in } \\
\text { the future out- } \\
\text { side the current } \\
\text { organization }\end{array}$} & $25-31$ & & & $0.2290 * *$ & \\
\hline & & $32-38$ & & & $0.2803^{* *}$ & \\
\hline & & $39-45$ & & & $0.2150^{* *}$ & \\
\hline \multirow{3}{*}{$\begin{array}{l}\text { Competing } \\
\text { to enjoy } \\
\text { the job }\end{array}$} & \multirow{3}{*}{ Job enjoyment } & $25-31$ & & & & $0.1779 * *$ \\
\hline & & $32-38$ & & & & $0.2099 * *$ \\
\hline & & $39-45$ & & & & $0.2948^{* *}$ \\
\hline
\end{tabular}

Note: X: improving the skills; M (Mediator): earnings/promotions/ability of professional development in the current organization/autonomy in the current organization; Y: relative wealth/professional prestige/ability of professional development outside the current organization in the future/job enjoyment.

The presentation of the findings starts with the most and least important facets of competitiveness. Comparison of the values of the indirect effects of improving the professional skills show that competing to self-develop is the most important facet of competitiveness for under 40-yearolds (the values of the indirect effects: 0.2290 and 0.2803 , respectively for age of 25-31 and 3238). The employees in this range of age are motivated to improve their work-related skills mainly by abilities to grow in their organizations and opportunities of professional development in the future outside the current organizations. They believe that broadening their skills is valuable for their chosen career. The employees at age of 39-45 also appreciate this motivation, however, competing to enjoy the job is the most important facet of competitiveness for them (the value of 
the indirect effect: 0.2948$)$. The older ones at their middle age (39-45) perceive improving their professional skills as an instrument to broaden their autonomy in their organizations. Independency, in turn, allows them to do what they like to do.

Competing to be well-off was shown to be the least important facet of competitiveness in each age group. Considering all four goals, working towards high relative wealth is the weakest motivator which stimulates employees to improve their professional skills among those included in the study.

Looking for further differentiation in the facets of competitiveness across the age groups, four considerable differences in the values of the indirect effects across the groups can be found. Firstly, the effect of improving the skills on relative wealth through earnings is almost twice as strong for the older employees in middle age (39-45) in comparison to two other groups (the indirect effects: $0.0644 ; 0.0677 ; 0.1246$ respectively for the age groups: $25-31 ; 32-38$ and 39-45). Secondly, regarding competing to avoid professional deprivation, the effect of improving skills on professional prestige through promotion decreases in the group of 32-38 in comparison to two other groups (the indirect effects: 0.1405 ; 0.1096; 1594 respectively for 25-31; 32-38 and 3945). Thirdly, a reverse tendency can be found in reference to competing in terms of self-development. The effect of improving skills on the opportunity for development in the future outside the current organization is the strongest only for the age group of 32-38 (the indirect effects: $0.2290 ; 0.2803 ; 0.2150$ respectively for the age groups: $25-31 ; 32-38 ; 39-45)$. Fourthly, there is a visibly increasing tendency in these age groups in the importance of competing to enjoy the job (the indirect effects: $0.1779 ; 0.2099 ; 0.2948$ respectively for the age groups: $25-31 ; 32-38$; 39-45).

These findings contribute to the literature on competitiveness and motivation in three ways. Firstly, this research confirms the Warr \& Birdi proposition (1998) that education can moderate the relationship between age and continuing education. Contrary to the findings of Warr \& Fay (2001) that older adults are less likely to engage in the future self-development intentions, this study shows that higher-educated employees pursue self-development to the largest extent in their 30s, and in the first half of their 40s; they devote attention to self-development more or less at the same level as higher-educated people under 30. This research relates such a high importance of self-development among the employees above 30 (up to 45) not only with the level of education, like Warr \& Birdi (2001), but also in terms of the quality of education. Up to $40 \%$ of the participants evaluated the quality of teaching at their universities as not high. This factor induces them to perceive improving their professional skills as an instrument that can provide them with the opportunity to progress in their career. Secondly, the findings from this study suggest that the strongest shift in the importance of two goals - professional prestige and self-development - appears at the age of 32-38, when the importance of professional prestige visibly declines, whereas the importance of self-development considerably increases (the indirect effects: 0.1096 and 0.2803 respectively). Thirdly, this research reveals that there is no one-way shift in motivation over time. Inceoglu et al. (2012), for example, suggest that older employees are less motivated by extrinsically-rewarding, but by more intrinsically-rewarding features. In this study, two results do not confirm this suggestion. In each age group, the participants were more strongly stimulated to improve their skills by less extrinsic forms of motivation. Moreover, 
it should be stressed that the effect of improving professional skills on relative wealth through earnings visibly increases just at the age of 39-45; the value of this indirect effect in this age group is twice higher than in two other groups (the indirect effects: 0.1246 and $0.677 ; 0.0644$ respectively in $39-45 ; 32-38 ; 25-31)$.

Finally, the gender effects of improving skills were found only for the age group of 39-45 in reference to two causal events: firstly, improving the skills $\rightarrow$ development in the organization $\rightarrow$ development in the future, secondly, improving the skills $\rightarrow$ autonomy $\rightarrow$ job enjoyment (see Table 2). In both cases, gender is statistically significant as a moderator (W), which influences the relationship between the variable X (improving the skills) and the mediator M (ability of professional development in the current organization, and autonomy in the current organization, respectively). Improving skills affects the capacity for professional development in the current organization at a rate of 55 percent more strongly in the case of men than with women (the conditional effects of the focal predictor (X: improving the skills) at values of the moderator (gender): $0.3752 ; 0.6805$ for women and men, respectively). The impact of improving skills on autonomy in the current organization is stronger for men than women by 61 percent. Consequently, in both casual events, the conditional indirect effects of X (Improving the skills) on $\mathrm{Y}$ (development in the future, and job enjoyment, respectively) are stronger for men than women (for the first casual event: 0.1675 and 0.3038 ; for the second casual event: 0.2398 and 0.3950 for women and men respectively).

Similarly to the results shown by Kanfer \& Ackerman (2000) as well as Warr (2008), these findings also point at the capacity for development and autonomy as more important motivators for men than women, however, only in the age range of 39-45. There is no such the gender differentiation in motivation up to the age of 40 in reference to higher-educated employees. Contrary to the results presented by Inceoglu et al. (2012), the present research shows no gender differences in the importance of professional prestige nor material status. In general, higher-educated women and men are motivated to improve their professional skills by the same motivators up to the end of their 40s, after which less extrinsic motivation (self-development and autonomy) become more important for men than women.

Tab. 2 - The significance of gender as a moderator, found only for employees of age 39-45. Source: Own calculation on a base of the models 7 and 14 in the Process Hayes in SPSS

\begin{tabular}{|c|c|c|c|c|}
\hline \multirow{2}{*}{$\begin{array}{l}\text { Outcomes } \\
\text { from Process } \\
\text { Hayes in } \\
\text { SPSS }\end{array}$} & \multicolumn{2}{|c|}{$\begin{array}{l}\text { improving the skills } \rightarrow \text { development in the organization } \rightarrow \\
\text { development in the future } \\
\text { Age: } 39-45\end{array}$} & \multicolumn{2}{|c|}{$\begin{array}{l}\text { improving the skills } \rightarrow \text { autonomy } \rightarrow \\
\text { job enjoyment } \\
\text { Age: } 39-45\end{array}$} \\
\hline & $\begin{array}{l}\text { Model } 7 \\
\text { X:improving the skills } \\
\text { Y:development in the future } \\
\text { M:development in the organiza- } \\
\text { tion } \\
\text { W: gender }\end{array}$ & $\begin{array}{l}\text { Model } 14 \\
\text { X:improving the skills } \\
\text { Y:development in the } \\
\text { future } \\
\text { M:development in the } \\
\text { organization } \\
\text { W: gender }\end{array}$ & $\begin{array}{l}\text { Model } 7 \\
\text { X:improving the } \\
\text { skills } \\
\text { Y:job enjoymentM: } \\
\text { autonomy } \\
\text { W: gender }\end{array}$ & $\begin{array}{l}\text { Model } 14 \\
\text { X:improving the } \\
\text { skills } \\
\text { Y:job enjoyment } \\
\text { M:autonomyW: } \\
\text { gender }\end{array}$ \\
\hline
\end{tabular}




\begin{tabular}{|c|c|c|c|c|c|c|c|c|}
\hline $\begin{array}{l}\text { Test of high- } \\
\text { est order } \\
\text { unconditional } \\
\text { interaction }\end{array}$ & \multicolumn{2}{|c|}{$\begin{array}{l}\mathrm{X}^{*} \mathrm{~W} \\
\mathrm{R}^{2} \text {-chng }=0.0148^{* *}\end{array}$} & \multicolumn{2}{|c|}{$\begin{array}{l}\mathrm{M}^{*} \mathrm{~W} \\
\mathrm{R}^{2} \text {-chng=0.0015 } \\
\text { Insignificant }\end{array}$} & \multicolumn{2}{|c|}{$\begin{array}{l}\mathrm{X}^{*} \mathrm{~W} \\
\mathrm{R}^{2} \text {-chng }=0.0220^{* *}\end{array}$} & \multicolumn{2}{|c|}{$\begin{array}{l}\mathrm{M}^{*} \mathrm{~W} ; \\
\mathrm{R}^{2} \text {-chng=0.0018 } \\
\text { Insignificant }\end{array}$} \\
\hline \multirow{4}{*}{$\begin{array}{l}\text { Conditional } \\
\text { effects of the } \\
\text { focal predictor } \\
\text { at values of } \\
\text { the moderator } \\
\text { (gender) }\end{array}$} & \multicolumn{2}{|c|}{ Focal predictor: $\mathrm{X}$} & \multicolumn{2}{|c|}{ Focal predictor: M } & \multicolumn{2}{|c|}{ Focal predictor: $\mathrm{X}$} & \multicolumn{2}{|c|}{$\begin{array}{l}\text { Focal predic- } \\
\text { tor: } \mathrm{M}\end{array}$} \\
\hline & Gender & Effect & Gender & Effect & Gender & Effect & Gender & $\begin{array}{l}\text { Ef- } \\
\text { fect }\end{array}$ \\
\hline & Women & $0.3752^{* *}$ & Women & insig. & Women & $0.4798^{* *}$ & Women & insig. \\
\hline & Men & $0.6805^{* *}$ & Men & insig. & Men & $0.7901^{* *}$ & Men & insig. \\
\hline \multirow{3}{*}{$\begin{array}{l}\text { Conditional } \\
\text { indirect ef- } \\
\text { fects of X } \\
\text { on Y }\end{array}$} & Gender & Effect & Gender & Effect & Gender & Effect & Gender & $\begin{array}{l}\text { Ef- } \\
\text { fect }\end{array}$ \\
\hline & Women & $0.1675^{* *}$ & Women & insig. & Women & $0.2398^{* *}$ & Women & insig. \\
\hline & Men & $0.3038^{* *}$ & Men & insig. & Men & $0.3950 * *$ & Men & insig. \\
\hline $\begin{array}{l}\text { Index of } \\
\text { moderated } \\
\text { mediation }\end{array}$ & $\begin{array}{l}\text { Gender: } \\
\text { In- } \\
\text { dex }=0.1363^{* *}\end{array}$ & $\begin{array}{l}\text { Gender: } \\
\text { Index }=0.0381 \\
\text { Insignificant }\end{array}$ & $\begin{array}{l}\text { Gender: } \\
\text { Index } \\
=0.1552^{* *}\end{array}$ & $\begin{array}{l}\text { Gender:In- } \\
\text { dex }=0.0570 \\
\text { Insignificant }\end{array}$ & & & & \\
\hline
\end{tabular}

Note: $\mathrm{M}=$ mediator; $\mathrm{W}=$ moderator; Index of moderated mediation is the difference between conditional indirect effects. insig.: statistically insignificant effect; ** significance at 5\%.

\section{LIMITATIONS AND FURTHER STUDIES}

This research uses cross-sectional data, i.e. findings which are not able to investigate changes over time, for which longitudinal data are usually recommended. Taking into account that a person does not necessarily progress through each type of motivation, investigating the age groups on a basis of cross-sectional data does not seem to be an important limitation.

Although including only well-educated participants in mobile-working age was intentional, such a choice limits the interpretation of the findings to this group. Further studies could cover the overall adult population.

\section{CONCLUSIONS}

This study empirically investigated age- and gender-differences between employees in terms of the motivation toward training. Our examination considers four facets of competitiveness and three types of orientation in terms of extrinsic motivation. An empirical analysis was carried out among the higher-educated employees in Poland.

A comparison of the values of the indirect effects in terms of improving professional skills showed that competing with the goal of self-development was the most important facet of competitiveness for under 40-year-olds, while competing to enjoy the job was shown to be the case for employees of age 39-45.

Competing to be well-off was indicated to be the least important facet of competitiveness for each age group. Working towards higher relative wealth was the weakest motivator which stimulated employees to improve their professional skills among those included in the study.

Higher-educated women and men were motivated to improve their professional skills by the same motivators up to the end of their 40 s, after which less extrinsic motivation (self-develop- 
ment and autonomy) became more important for men than women.

A number of recommendations can be extrapolated from our findings for employers in regards to how important particular motivators and goals can stimulate employees to improve their professional skills. Firstly, considering higher-educated people at mobile-working age (25-45), there is no declining tendency in the importance of self-development. Employers should differentiate training in such a way as to perceptibly broaden the professional skills at every age and to create the ability to grow in every career stage. Considering employees above 40 , this recommendation holds much stronger in reference to men than to women. Secondly, taking into account the increasing importance of job enjoyment with age, employers should offer experienced employees with higher skills more autonomy. Improving skills must lead to more independence within the organization with increased age, especially considering men above 40. Thirdly, employees above 40 years expected a pay rise resulting from skills improvement, a result which was notably larger compared with those below 40 .

Although our findings result from research based on competitiveness as a personality trait, the recommendations following from these results should prove useful to increase economic competitiveness. Taking into account these parameters will allow employers to adjust the motivators of job training to expectations of specific age and gender groups of employees. Well-motivated employees make training more efficient, i.e. augmenting human capital contributes to a growth in productivity within the larger economy. A productive economy means a competitive economy.

\section{Acknowledgements}

This work was supported by the National Centre for Science [grant numbers 2015/17//HS4/02713].

\section{References}

1. Böheim, R., Grübl, D. \& Lackner, M. (2017). Gender Differences in Competitiveness. Ifo DICE Report 2 / 2017 June Volume 15.

2. Carifio, L., \& Perla, R. (2008). Resolving the 50 Year Debate Around Using and Misusing Likert Scales. Medical Education, 42 (1), 1150-1152. https://doi.org/10.1111/j.13652923.2008.03172.x

3. Chuang, A., Shen, Ch-T., \& Judge, T. A. (2016). Development of a Multidimensional Instrument of Person-Environment Fit. Applied of Psychology, 65 (1), 66-98. https://doi. org/10.1111/apps.12036

4. Crosby, F. A. (1984). Relative Deprivation in Organizational Settings, In: B. M. Staw \& L. L. Cummings, Eds., Research in Organizational Behavior, CT: JAI Press.

5. Darlington, R. B. \& Hayes A. F. (2016). Regression Analysis and Linear Models: Concepts, Applications, and Implementation. GUILFORD PUBLICATIONS, 1, 661. .

6. Deci, E. L., \& Ryan, R. M. (1985). Intrinsic Motivation and Self-determination in Human behavior. New York: Plenum.

7. Cavanaugh, J. C., \& Blanchard-Fields, F. (2006). Adult Development and Aging (5th edition) Belmont, CA: Wadsworth Publishing/Thomson Learning. 
8. Dunlap, H. F. (1931). An Empirical Determination of Means, Standard Deviations and Correlation Coefficients Drawn from Rectangular Distributions. Annals of Mathematical Statistics, 2 (1), 66-81.

9. Griffin-Pierson, S. (1990). The Competitiveness Questionnaire: a Measure of Two Components of Competitiveness. Measurement \& Evaluation in Counseling \& Development. 23 (3), 108-115.

10. Guerrero, S., \& Sire, B. (2001). Motivation to Train from the Workers' Perspective: Example of French Companies. International Journal of Human Resource Management, 12 (6), 988-1004.

11. Havlicek, L. L., \& Peterson, N. L. (1976). Robustness of the Pearson Correlation Against Violation of Assumption. Perceptual and Motor Skills, 43 (3), 1319-1334. https://doi. org/10.2466/pms.1976.43.3f.1319

12. Hayes, A. F. (2013). Introduction to Mediation, Moderation, and Conditional Process Analysis: A Regression-Based Approach. New York: Guilford Press

13. Hibbard, D., \& Buhrmester, D. (2010). Competitiveness, Gender, and Adjustment among Adolescents. Sex Roles. 63 (5-6), 412-424. https://doi.org/10.1007/s11199-010-9809-z

14. Inceoglu, I., Segers, J., \& Bartram, D. (2012). Age-related Differences in Work Motivation. Journal of Occupational and Organizational Psychology, 85 (2), 300-329

15. Jamieson, S. (2004). Likert Scales: How to (Ab)use Them. Medical Education, 38 (12), 1217-1218. https://doi.org/10.1111/j.1365-2929.2004.02012.x

16. Kanfer, R., \& Ackerman, P. L. (2004). Aging, Adult Development, and Work Motivation. Academy of Management Review, 29 (3), 440-458.

17. Kanfer, R., \& Ackerman, P. L. (2000). Individual Differences in Work Motivation: Further Explorations of Trait Framework. Applied Psychology: An International Review, 49 (3), 470-482.

18. Kayhan, E. (2003). Two Facets of Competitiveness and Their Influence on Psychological Adjustment. Honors Projects. Paper 4. Available at: http://digitalcommons.iwu.edu/psych_ honproj/4

19. Lee, J. Y., Lyoo, I. K., Kim, S. U., Jang, H. S., Lee, D. W., Jeon, H. J., Park, S. C., \& Cho, M. J. (2005). Intellect Declines in Healthy Elderly Subjects and Cerebellum. Psychiatry and Clinical Neurosciences, 59 (1), 45-51.

20. Maehr, M. L., \& Kleiber, D. a. (1981). The Graying of Achievement Motivation. American Psychologist, 36 (7), 787-793.

21. Maurer, T. J., Weiss, E., \& Barbeite, F. (2003). A Model of Involvement in WorkRelated Learning and Development Activity: The Effects of Individual, Situational Motivational, and Age Variables. Journal of Applied Psychology, 88 (4), 707-724. https://doi. org/10.1037/0021-9010.88.4.707

22. Nicholls, J. G. (1984). Achievement Motivation: Conceptions of Ability, Subjective Experience, Task Choice, and Performance. Psychological Review, 91 (3), 328-346.

23. Norman, G. (2010). Advances in Health Sciences Education. Methodologist's Corner, 15, 625. 
https://doi.org/10.1007/s10459-010-9222-y

24. Nnambooze, B. E., \& Parumasur, S. B. (2016). Understanding the Multigenerational Workforce: Are the Generations Significantly Different or Similar? Corporate Ownership and Control, 13(2), 224-237. https://doi.org/10.22495/cocv13i2c1p4

25. Orosz G., Toth-Kiraly I., Buki N., Ivaskevics K., Bothe B., \& Fulop M. (2018). The Four Faces of Competition: The Development of Multidimensional Competitive Orientation Inventory. Frontiers in Psychology, 9, 779, https://doi.org/10.3389/fpsyg.2018.00779

26. Pearson, E. S. (1931). The Analysis of Variance in the Case of Non-normal Variation. Biometrika, 23 (1), 114-133.

27. Pearson, E. S. (1932a). The Test of Significance for the Correlation Coefficient. Journal of the American Statistical Association, 27 (1), 128-134.

28. Pearson, E. S. (1932b). The Test of Significance for the Correlation Coefficient: Some Further results. Journal of the American Statistical Association, 27 (1), 424-426.

29. Ryan, R. M. (1982). Control and Information in the Intrapersonal Sphere: An Extension of Cognitive Evaluation Theory. Journal of Personality and Social Psychology, 43 (3), 450-461.

30. Ryan R. M.,\& Deci, E. L. (2000). Intrinsic and Extrinsic Motivations: Classic Definitions and New Directions. Contemporary Educational Psychology, 25 (1), 54-67, https://doi. org/10.1006/ceps.19999.1020

31. Schaie, K. W. (2005). Developmental Influences on Adult Intellectual Development: The Seattle Longitudinal Study. New York: Oxford University Press.

32. Social Diagnosis, reports. (2003, 2007-2018). Czapinski J., \& Panek T. (Ed.). Social diagnosis. www.diagnoza.com

33. Townsend P. (1979). Poverty in the United Kingdom: A Survey of Household Resources and Standards Living. Penguin Books.

34. Turska E. (2017). Kapitat kariery ludzi mtodych - Cz 2 Kapitat kariery ludzi mtodych Badania własne. Uniwersytet Śląski.

35. Warr, P. (2008). Work Values: Some Demographics and Cultural Correlates. Journal of Occupational and Organizational Psychology. 81 (4), 751-775.

36. Warr, P., \& Birdi, K. (1998). Employee Age and Voluntary Development Activity. International Journal of Training and Development, 2 (3), 190-204.

37. Warr, P. \& Fay, D. (2001). Short Report: Age and Personal Initiative at Work. European Journal of Work, and Organizational Psychology, 10 (3), 343-353.

38. World Economic Forum. (2016). What Is Competitiveness. Retrieved from https://www. weforum.org/agenda/2016/09/what-is-competitiveness 
Contact information

prof. of associate Maria Piotrouska, Ph.D.

University: Wroclaw University of Economics

Faculty: Economic Science

Department (Institute): Economics

Poland

E-mail:maria.piotrowska@ue.wroc.pl 